\title{
Divida Pública e Absorção de Capital de Empréstimo: Elementos para Análise da Atual Crise Financeira Mundial
}

\author{
José Raimundo Barreto Trindade ${ }^{1}$
}

\begin{abstract}
Resumo: Este artigo se propõe analisar especificamente a função que a divida pública das economias centrais cumpre de "absorver capital de empréstimo", ou seja, retirar parcela da massa de valores monetários da economia e recondicioná-las na forma de títulos de capital fictício de elevada credibilidade, com consequências sobre a estrutura de dinheiro de crédito da economia capitalista global e sobre a própria estabilidade cíclica do sistema. Para isso analisam-se a forma Capital de Empréstimo e Capital Fictício, ressaltando a objetividade da análise marxista quanto aos fenômenos monetários ou mais apropriadamente creditícios; em seguida analisa-se a especulação, considerando a percepção de que os valores fictícios devam ser "reciclados" e que a especulação sucede do descolamento do crédito de sua base real, que é o crédito monetário; no momento seguinte aborda-se a interação entre sistema de crédito e sistema de divida pública e, finalmente se desenvolve a anunciada função absorção de capital de empréstimo, observando-se que esta funcionalidade encontra limites frente ao "germe da crise futura muito mais violenta".
\end{abstract}

Palavras-chave: Divida Pública; Sistema de Crédito; Capital de Empréstimo; Marx.

JEL: B, B5, B51; H, H6, H69 


\title{
Public Debt and Absorption Loan Capital: Elements for the Analysis of the Current Financial Crisis
}

\begin{abstract}
This article proposes to examine specifically the role that the public debt of the central economies meet to "absorb loan capital," ie, removing part of the mass of the monetary values of the economy and recondition them in the form of equities fictional high credibility, with consequences on the structure of credit money of the global capitalist economy and the own stability of the cyclic system. For this we analyze the shape Loan Capital and Fictitious Capital, emphasizing the objectivity of the Marxist analysis regarding monetary phenomena or more appropriately credit, and then analyzes the speculation, considering the perception that the fictitious values must be "recycled" and that speculation succeeds of the decoupling of the credit of his real basis, which is credit money, the next moment discusses the interaction between system and credit system of public debt, and finally develops announced absorption function of loan capital, noting that this function is the front limits the "germ of future crisis much more violent."
\end{abstract}

Keywords: Poverty; Spatial Analysis; Paranaense Economy.

JEL: B, B5, B51; H, H6, H69

\section{Introdução}

A atual crise capitalista mundial expõe de forma bastante nítida a interação entre o crédito público e o modus operandi do sistema financeiro, demonstrando as particulares relações entre as finanças do Estado e o sistema de crédito global. A atual crise da divida soberana estabelecida na Europa segue um rastilho que se inicia ainda na década de 80 quando da incapacidade de refinanciamento das chamadas economias emergentes, sendo que na década de 90 são particularmente agudas as crises localizadas: mexicana, russa, brasileira e que culmina na quebra da economia da Argentina em 2001 ${ }^{1}$.

Compreendemos que a análise das funções creditícias do sistema de divida pública devem ser melhor investigadas sob o ponto de vista marxista, isso porque ela comparece como um sistema mais organizado e estável, regulando os fluxos de capital de empréstimo e capital fictício a partir da atuação do Banco Central e do Tesouro Nacional das principais economias capitalistas centrais, na atualidade especificamente EUA e Alemanha.

1 Para um meticuloso levantamento das recorrentes crises, especialmente financeiras, nas últimas duas décadas e com diferentes interpretações, vale conferir: Serfati (2006); Belluzo (2009); Stiglitz (2010); Altvater (2010); Harvey (2011). 
Neste artigo se propõe analisar especificamente a função que a divida pública cumpre de "absorver capital de empréstimo", ou seja, retirar parcela da massa de valores monetários da economia e recondicioná-las na forma de títulos de capital fictício de elevada credibilidade, com consequências sobre a estrutura de dinheiro de crédito da economia capitalista global e sobre a própria estabilidade cíclica do sistema. Essa tese relaciona-se ao que alguns autores marxistas vêm como um aparente paradoxo: a crescente divida pública estadunidense como elemento de consolidação do sistema financeiro internacional (Serfati, 2006; Harvey, 2011).

O trabalho está dividido em seis partes além desta introdução. Na primeira seção analisa-se as formas Capital de Empréstimo e Capital Fictício, ressaltando a objetividade da análise marxista quanto aos fenômenos monetários ou mais apropriadamente denominados creditícios; no segmento seguinte analisa-se a especulação, considerando a percepção de que os valores fictícios devam ser "reciclados" e que a especulação sucede do descolamento do crédito de sua base real, que é o crédito monetário; a terceira seção destina-se a analisar brevemente a interação entre sistema de crédito e sistema de divida pública; a quarta e quinta seções destinam-se a analisar a função absorção de capital de empréstimo e enunciar, respectivamente, como esta funcionalidade encontra limites frente ao "germe da crise futura muito mais violenta", tal como a presente crise global se apresenta; finalmente traçam-se as considerações finais.

\section{Capital de Empréstimo e Capital Fictício}

O desenvolvimento da forma capital de empréstimo resulta da paulatina dissociação entre propriedade e uso da riqueza econômica, o que é característico das relações de produção capitalista. A primeira e mais importante manifestação desta dissociação se dá com a alienação da força de trabalho, que, ao transformar-se em mercadoria, dissocia propriedade e uso desta, que adquire um valor de troca para o trabalhador igual à taxa média de salário e um valor de uso para o capitalista referente à capacidade de produção de mais-valia.

O lucro, forma da mais-valia obtida pelo capitalista com a exploração do trabalhador produtivo, oculta, do mesmo modo, aquela relação de apropriação mediante o expediente da formação da taxa de lucro, uma magnitude que não contrapõe o excedente econômico (mais-valia) ao capital variável, real expressão da taxa de exploração, e sim pela contraposição da mais-valia ao capital total (constante e variável) adiantado na produção. Deste modo, o lucro e a taxa de lucro representam o passo seguinte de um processo de reificação econômica materializada na percepção vulgar de que o capital é capaz de per si produzir valor.

A forma juro constitui uma segunda potência dessa dissociação formal da 
produção do valor em relação ao real processo de produção da riqueza material, passando a ser visto, conforme a teoria econômica quantitativista, como decorrente da natureza do capital. Como observou Marx (1985c, p. 1502): “o juro, e não o lucro, configura assim a geração de valor decorrente do capital como tal e, portanto, da propriedade do capital; daí ser visto [pelos economistas vulgares] como a renda especificamente gerada pelo capital".

O capital de empréstimo é funcional à acumulação capitalista, mesmo sendo uma expressão relativamente autônoma do capital industrial. A sua funcionalidade relaciona-se não ao capital produtivo em si, mas à mobilidade do capital, resultante que é da ativação contínua de capital-dinheiro latente, possibilitado pelo sistema de crédito. Essa autonomia de fato tem que ser qualificada. Não há autonomia real do capital de empréstimo quanto ao capital produtivo no sentido de essa forma (capital de empréstimo) expandir-se independentemente (D-D'). Seu movimento oscilatório geral é dependente dos movimentos da acumulação reprodutiva e sua expansão real das reservas monetárias reais acumuladas no circuito de crédito.

A autonomia refere-se a dois fatores: i) as magnitudes de valores-renda que se amoedam e também alimentam a reserva monetária e, portanto, expandem o capital de empréstimo. Estas rendas (juros, renda da terra, poupanças salariais etc.) são provenientes de algum ponto do circuito reprodutivo; ii) a capacidade do sistema de crédito de aumentar a velocidade rotacional do capital, liberando para empréstimo novas parcelas de valores-capital. Ambos os movimentos determinam que o capital de empréstimo total da economia ande sempre à frente das demandas reprodutivas por capital de empréstimo e a essas necessariamente acrescem as demandas não reprodutivas, o que pode de algum modo criar tensões no sistema.

O sistema de crédito como forma de mobilização do capital produtivo caminha lado a lado com a fomentação de outros diversificados usos do capital de empréstimo, desde o financiamento do Estado, por meio de emissão de títulos públicos, ao financiamento de capital fixo por emissão acionária, até o financiamento de recompra de títulos no mercado secundário, conformando uma impressionante massa de valores virtuais representados em diferenciadas formas de títulos ou direitos de propriedade.

Os grandes números que envolvem aquilo que diversos autores chamam de “acumulação financeira” (por exemplo, Harvey, 1990, 2008; Duménil, 2003, 2005; Chesnais, 1998, 2005) determinam um elevado grau de impressionismo na análise do sistema de crédito internacional: "No fim dos anos 90, o volume de ativos" (papéis de crédito diversos) "em posse do conjunto dos investidores institucionais ultrapassava US\$ 36 trilhões. Esses haveres representavam em 
torno de 140\% do PIB dos países da zona da OCDE” (Chesnais, 2005:43)². Esse processo encadeado de uso generalizado do crédito e de expansão relativamente autônoma do capital de empréstimo leva ao desenvolvimento da forma mais abstrata de capital: o capital fictício ${ }^{3}$.

O capital fictício é, portanto, uma forma específica do capital de empréstimo e cumpre funções específicas, mas em nome do capital de empréstimo. Sua existência em termos sistêmicos é nominal, em oposição ao seu valor real que foi completamente destruído (título público) ou assimilado ao capital acionário da empresa.

A importância do capital fictício encontra-se, em dois aspectos correlatos: i) por sua específica faculdade de mobilizar fundos que financiam, por um lado, grande parte do capital fixo da economia, como no caso do lançamento de ações, ou, como no caso dos títulos públicos, financia os gastos militares e o patrimônio do Estado e; ii) a desvalorização desses títulos e sua aquisição por novos proprietários são um dos principais mecanismos de transferência de riqueza e centralização de capital.

\subsection{A mobilização de capital de empréstimo real}

Uma das principais funções do capital fictício é a de mobilização de recursos capazes de financiar o "capital fixo" da economia e da infraestrutura pública. É sobre a base objetiva (valor de uso) do financiamento dessas duas formas de imobilização de riqueza, que se desenvolvem as principais formas de capital fictício (capital acionário e dívida pública).

Tanto o financiamento do capital fixo quanto o patrimônio estatal requerem expressivas magnitudes de riqueza acumulada. Por outro lado, na medida em que os valores envolvidos nestas formas de dispêndio apresentam, no caso do capital fixo, um tempo de retorno longo e, no caso dos gastos estatais, um não retorno (na medida em que dissipa completamente o valor original), o sistema de crédito se tornou vital para dar vazão às necessidades de investimento produtivo de longo prazo e para fazer frente aos crescentes gastos estatais.

O capital de empréstimo tem na sua forma monetária o principal atributo de flexibilidade para uso e mobilidade. Sua dimensão de ser valor-capital destinado a empréstimo (e não a venda) encontra nas duas formas - capital fixo e infraestrutura pública - barreiras a sua mobilidade, na medida em que necessita se converter em valores de uso específicos ("bens públicos", ferrovias, maquinaria, etc.). Na medida em que o capital de empréstimo se

\footnotetext{
2 Harvey (2008, p.173) denomina de "financialização" a expansão desregulada do sistema financeiro, sendo que "o volume diário total de transações financeiras nos mercados internacionais, que alcançava 2,3 bilhões de dólares em 1983, elevou-se a 130 bilhões por volta de 2001”. Serfati (2006, p.13) observa que a crescente desregulamentação e descompartimentalização dos mercados financeiros, somados a contabilidade criativa neoliberal "levaram à criação desenfreada de capital fictício". 3 "The concept of capital as a whole moves from the category of ideas to an actual social category, as capitalist own capital in general, inits most abstract form, fictious capital" (WEEKS, 198, p. 131).
} 
compromete com esses específicos valores de uso, perde sua flexibilidade, ensejando barreiras ao processo de circulação do capital de empréstimo no interior do sistema de crédito, o que é parcialmente resolvido com a emissão dos títulos que constituem o capital fictício.

Essa função mobilidade do capital de empréstimo permitida pelo capital fictício decorre de suas características intrínsecas, ou seja, ao ser uma forma desmaterializada e facilmente transferível de propriedade, permite a maior integração possível dos diferentes circuitos de acumulação dispersos no espaço econômico capitalista mundial e, por outro lado, possibilita também, por meio da classificação feita pelas empresas de rating, o estabelecimento, por exemplo, de mecanismos de transferência de rendas globais de um circuito de acumulação mais mal classificado para um mais bem classificado ${ }^{4}$.

O principal mecanismo assinalado por Marx que possibilitaria a maior mobilidade dos recursos investidos em capital fixo é a emissão de capital acionário. Os títulos de ações oferecidos pelas empresas representam um montante de valor que tem por base o capital empregado na aquisição dos meios de produção, duplicando o valor gasto nesses meios produtivos. A oferta desses títulos garante a circulação de valores que somente se realizarão no futuro, porém assegurados em uma massa de valores de uso cuja capacidade de depreciação é relativamente independente da desvalorização dos papéis de representação de valor ou títulos de ação.

Posteriormente, no mercado de títulos, esses papéis se autonomizam relativamente, passando a ser negociados como uma mercadoria especial que, ao ser comprado, converte seu rendimento capitalizado pela taxa de juro em uma importância monetária que pode ser utilizada na aquisição de meios produtivos ou gasta como renda. Esse capital monetário existe como transferência de valor e para o vendedor do título implica reaver capital de empréstimo real.

O capital fictício constitui campo de aplicação do capital de empréstimo, portanto concorre diretamente com o capital produtivo pelos fundos disponíveis. O capital produtivo apresenta o duplo movimento de diástole e sístole monetária, atuando na alimentação do circuito e, ao mesmo tempo, retirando massa monetária necessária à aquisição das mercadorias produtivas (meios de produção e força de trabalho). Necessariamente o processo de contração monetária efetuada no ciclo produtivo (D) é inferior à expansão monetária decorrente desse mesmo capital, após o processo de valorização e realização da mais-valia $(\mathrm{D}+\Delta D)$.

\footnotetext{
4 As empresas de rating, como a Standard \& Poor's, a Fitch Ratings e a Moody's, têm modelos próprios para classificação de risco e rentabilidade dos títulos. Nos EUA, por exemplo, os bancos utilizam a securitização de valores mobiliários como garantia para empréstimos de curto prazo tomados de administradores de fundos e outros tipos de investidores. De acordo com a Fitch Ratings "as operações de recompra garantidas por dívidas estruturadas normalmente rendem 50 pontos-base. As que são garantidas por títulos do tesouro dos EUA ou por papéis de agências (...) rendem apenas 5 e 15 pontos-base, respectivamente" (ALLOWAY, Valor Econômico, 06/02/2012, p. C2). Para uma análise crítica, mas não marxista, desse sistema de rating conferir Stiglitz (2010, p. 43-46).
} 
O mercado financeiro, considerando suas principais instituições: o sistema bancário, o mercado de títulos da dívida pública e a bolsa de valores, possibilita uma contínua transformação de valores fictícios em valores monetários (dinheiro de crédito), alimentando o circuito produtivo de novo capital de empréstimo. Os títulos referentes ao capital fictício apresentam deste modo, uma posição restrita e limitada na circulação de créditos. Por um lado requer um mercado específico para sua realização como mercadoria (o mercado de títulos da dívida pública e a bolsa de valores), por outro, no âmbito do sistema bancário sua troca requer a intermediação de fundos que garantam sua remonetização, o que reflete o movimento autônomo, com características próprias de circulação e concentração desses valores fictícios.

\subsection{A centralização do capital de empréstimo}

A expansão do capital fictício como componente funcionalmente necessário à mobilização de valores que garantam a reprodução espiral crescente do capital estabelece importantes modificações na forma institucional de gestão e propriedade do capital ${ }^{5}$. A centralização do capital é uma decorrência direta do processo de titulização das dívidas, ou seja, a sua conversão em títulos, decorrente tanto da transformação da propriedade individual ou familiar em propriedade acionária quanto pelo controle das finanças do Estado.

Em momentos de crise no mercado monetário, esses títulos são duplamente desvalorizados, tanto pela elevação da taxa de juro, em função do comportamento da demanda e oferta de capital de empréstimo, quanto pela elevação da oferta específica desses ativos, cujos portadores nominais tentam se desfazer a fim de obterem recursos monetários para fazer frente às dividas vincendas. Esse mecanismo de destruição de capital nominal da sociedade e a transferência de propriedade possibilitada por sua negociação é um importante aspecto a ser considerado, na medida em que a destruição deste tipo de valor de crédito não atinge os valores de uso (meios de produção), a redução nominal do capital social e a nova configuração mais centralizada da propriedade podem resultar até mesmo em condições reprodutivas mais favoráveis (Marx, 1985b, p. 932).

Ao analisar o capital fictício e a pirâmide de valores que caracteriza o sistema de crédito das finanças, um dos aspectos característicos desse sistema em crise refere-se a permanente "busca pela qualidade" dos títulos que compõem o capital bancário, isso ao mesmo tempo em que se reforça o caráter especulativo do sistema, algo que pode ser visto como um acelerado processo de reciclagem do capital fictício, como se verá a seguir.

5 Duménil\&Lévy (2005, p.87) observam que a clássica relação de propriedade individual ou familiar das empresas há muito foi substituída pela "propriedade financeira das sociedades (quer dizer, exercida por intermédio da posse de títulos), em que o poder dos proprietários se concentra nas instituições financeiras". 6 Em relação ao movimento de "fuga para a qualidade" Belluzzo (2010, p.122) enfatiza que em "uma crise financeira, como a que ora atravessamos, os títulos públicos dos países dominantes revelam sua natureza de ativos de última instância, abrigo em que encontra refrigério a angústia (...) dos possuidores e controladores privados da riqueza”. Interpretação semelhante pode ser constatada em Dupont\&Sack (1999); Wray (2003); Chesnais (2005). 


\section{Especulação e Reciclagem de Capital Fictício}

Deve-se considerar que, como elemento central do sistema de dívidas, todo e qualquer título remunerado por juro é a priori título sobre trabalho futuro, direito à parte dos valores de mercadorias ainda inexistentes, estando sujeito a três condições possíveis, independentes das condições efetivas de reprodução do capital real: i) remuneração regular com pagamento de juro sem oscilação do valor futuro (valor de face do título) em relação ao valor presente; ii) remuneração regular, porém com divergência entre valor presente e valor futuro, ou seja, valorização ou depreciação do título; iii) a completa desvalorização do título, que se manifesta na interrupção do pagamento da renda ou remuneração regular (default).

A possibilidade da ocorrência de qualquer uma das condições acima estabelece a base objetiva de especulação em torno dos títulos de capital fictício. A especulação é, antes de tudo, a exploração da variação dos preços, não a variação convencional e estritamente regulada pela lei do valor referente às mercadorias, e sim as oscilações bursáteis dos preços desses títulos 7 . $\mathrm{O}$ mercado especulativo existe como componente necessário da dinâmica geral de transformação dos capitais estagnados ou ociosos em fundos de reserva sob a forma de papéis, somente representativos de valores futuros, porém convertíveis em capitais monetários de empréstimo real para uso produtivo ${ }^{8}$.

As flutuações dos preços desses papéis estão relacionadas ao nível e à segurança dos seus rendimentos, fator dependente de aspectos objetivos e vinculados ao comportamento efetivo, seja do ciclo de negócios, seja do desempenho e lucratividade da empresa, ou as condições fiscais e macroeconômicas do país. Por outro lado, esses títulos, ao serem negociados nas bolsas de valores, podem sofrer efeitos puramente especulativos, alimentados pelos interesses de operadores e corretores da bolsa na valorização ou depreciação momentânea dos títulos em negociação. Hilferding (1985) refere-se às chamadas práticas de reporte, ou seja, a aquisição ou aluguel de títulos (ações ordinárias) com o objetivo de influenciar decisões executivas de uma corporação industrial por parte de um grande banco, por exemplo.

Outras práticas, formalizadas no âmbito das negociações da bolsa de valores, tais como a backwardation e o contango ${ }^{9}$, reforçam a percepção da bolsa de valores como espaço privilegiado de negociação e especulação dos títulos

7 Chesnais (2005, p. 60), com base em Lordon, trabalha com a "hipótese de insaciabilidade da finança", ou seja, a "contradição entre valorização financeira exigida e valorização econômica possível”. Harvey (2008, p.173-178) utiliza o termo "acumulação por espoliação" para caracterizar outro aspecto desse mesmo processo: a transferência de riqueza líquida de pontos diversos do planeta para as mãos da "haute finance".

8 "Esses títulos de dívida, emitidos em troca de capital originalmente emprestado e há muito tempo despendido, essas duplicatas em papel do capital destruído, servem de capital para os respectivos possuidores, na medida em que são mercadorias vendáveis e por isso podem ser reconvertidos em capital” (MARX, 1981b: p. 548) (grifos nossos).

9 Backwardation e contango são termos específicos do mercado financeiro londrino e se referem a postergação ou adiantamento da transferência de um título negociado em bolsa, a depender dos interesses de operadores (corretores) envolvidos no negócio (conferir SANDRONI, 2001). 
de renda. Do mesmo modo, mecanismos atuais como chamado "mercado de recompra" (repo market) constitui parcela importante do setor bancário desregulamentado ${ }^{10}$. A formação de um mercado puramente especulativo, tendo como base os títulos de capital fictício, constitui, contraditoriamente, condição necessária à contínua conversão de títulos de propriedade sobre valores futuros em capital monetário a ser disponibilizado e utilizado produtivamente no presente ${ }^{11}$.

O especulador não se vincula à lógica do capital reprodutivo, que é a obtenção do máximo lucro empresarial com base na diferença entre o preço de venda e o preço de produção de sua mercadoria. O ganho do especulador é tipicamente um lucro de alienação (profit upon alienantion), ou seja, sua capacidade de, tendo domínio de informação ou influência sobre o mercado de títulos, estabelecer o melhor momento para comprar ou vender seus títulos ${ }^{12}$. A diferença teórica central entre aquelas análises que tomam a especulação como derivada da "onisciência" do "agente especulador", tal como está presente nas análises keynesianas dos "insiders e outsiders"13 , e a análise marxista encontra-se justamente em localizar na categoria de capital fictício o pano de fundo objetivo para desenvolvimento da atuação do especulador.

Denominamos de reciclagem ${ }^{14}$ de capital fictício o movimento permanente de desvalorização (destruição) de títulos, sua substituição por novos títulos de capital fictício ou conversão de capital fictício em capital monetário. Esse processo de reciclagem de títulos de capital fictício é um movimento interno ao sistema de crédito, parcialmente regulado pelas autoridades monetárias, mesmo que em grande medida efetuado por meio de bancos e bolsas de valores.

A regulação desse mecanismo é fundamental para a manutenção "das propriedades monetárias" do dinheiro de crédito, evitando, até algum limite crítico, sua depreciação, mediante processo inflacionário. Marx (1981b, p. 593) faz a seguinte observação: "Depreciar o dinheiro de crédito (para não falarmos em destituí-lo imaginariamente das propriedades monetárias) abalaria todas as condições existentes. Por isso, sacrifica-se o valor das mercadorias, para assegurar que exista no dinheiro [de crédito] esse valor mítico e autônomo”.

\section{Parece-nos que Marx entendia essa perda de propriedades monetárias com}

$10 \mathrm{O}$ "mercado de recompra" (repo market) constitui parcela importante do setor bancário, abrange atividades e instituições financeiras desregulamentadas, sendo que o atual mercado de recompra dos EUA valeria algo em torno de US\$ 1,6 trilhão (ALLOWAY, Valor Econômico, 06/o2/2012, p. C2).

11 “(...) a especulação com os títulos (...) cria um mercado acolhedor; dá assim a possibilidade para que outros círculos capitalistas [os que mantêm os títulos como reserva de valor] transformem seu capital fictício em capital real; cria, portanto, o mercado para operação do capital fictício e, com isso, a possibilidade da troca contínua de investimentos em capital fictício e sua contínua nova transformação em capital monetário”. (HILFERDING, 1985, p. 141).

12 Segundo Hilferding (1985:139), o especulador "não conserva os títulos na esperança de auferir lucros elevados - isso faz o capitalista inversionista -, mas procura ganhar mediante a compra e venda de seus títulos". 13 Bastante ilustrativo é o trabalho de Kindleberger (2000).

14 Reciclagem é aqui utilizado propositadamente. Segundo o dicionário Aurélio, reciclar significa: "reaproveitar (material usado) ou atualizar (conhecimento)". Estamos utilizando o termo com os dois sentidos, pois, ao mesmo tempo em que se reaproveita algo já utilizado, atualiza-se sua forma, mediante nova emissão ou resgatando sua forma monetária. 
o sentido de inflação. Deve-se notar que a depreciação do dinheiro de crédito relaciona-se à desvalorização dos títulos de dívida em geral, o que determina um conjunto expressivo de problemas, desde mudanças no controle patrimonial, podendo afetar a acumulação real caso o processo falimentar de empresas leve à completa paralisação de suas atividades produtivas.

Sustentamos que o processo de regulação da reciclagem de capital fictício se dá principalmente mediante interferência do Estado, pela compra e venda de títulos públicos no mercado secundário de títulos públicos (open market) e com o uso necessário de reservas monetárias (via receita fiscal) para conversão de parcela dos valores fictícios em valores reais.

Esse mesmo processo, observado muito embrionariamente por Hilferding (1985), é que estamos denominando de reciclagem de capital fictício ${ }^{15}$. Nosso entendimento é que as observações do marxista austríaco eram corretas ante as peculiares condições do sistema financeiro alemão da época (final do século XIX, início do século XX). A pequena participação de títulos do tesouro até a Primeira Guerra Mundial (Horne, 1972) e a relativa autonomia entre a Bolsa de Valores e o sistema bancário, o que modernamente será denominado de "descompartimentalização dos mercados financeiros" (Chesnais, 2005, P. 46), seriam fatores marcantes das diferenças entre a conjuntura capitalista da primeira década do século XX em relação à conjuntura atual.

Ressalte-se, finalmente, que a expansão das formas fictícias de capital estabelece uma enorme distorção entre o volume de valores referentes aos direitos de propriedade (títulos de dívida) e a acumulação real. Os movimentos de valorização e desvalorização desses títulos são meras oscilações contábeis, não estando necessariamente vinculados ao movimento de valorização do capital efetivo que representam ou do capital destruído, portanto um não capital. No caso dos títulos da dívida pública das economias centrais é mais denotado que os movimentos de valorização e desvalorização deles não representam perda ou ganho real de riqueza e sim transferência e centralização de poder econômico. Vale observar que em períodos de crise os bancos buscam desesperadamente "limpar" suas carteiras de aplicação, o que de outro modo converge para tornar os títulos públicos dos países dominantes em ativos preferenciais (Belluzzo, 2005, 2010; Chesnais, 2005) ${ }^{16}$.

Contudo os movimentos críticos desses capitais fictícios não são de modo nenhum negligenciáveis sob o ponto de vista das condições de desenvolvimento

15 Hilferding (1985, p.140-141) observa que: "a especulação com os títulos (...), cria um mercado acolhedor; dá assim a possibilidade para que outros círculos capitalistas transformem seu capital fictício em capital real; cria, portanto, o mercado para a operação do capital fictício e, com isso, a possibilidade da troca contínua de investimentos em capital fictício e sua contínua nova transformação em capital monetário".

16 Como é visível na atual crise, mesmo países centrais, como a Itália e a França, passam a ter questionamento quanto a sua capacidade de validar completamente os títulos públicos, o que identifica limite estrutural a capacidade de reciclagem de capital fictício. Os sinais estruturais são identificáveis nos próprios mecanismos de segurança que o sistema financeiro desenvolveu. Assim, por exemplo, a elevação dos mercados de Credit Default Swaps (CDS) - derivativos que seguram o credor diante de um default do devedor - aponta desvalorização futura ou destruição pura e simples de grande massa de capital fictício (conferir OAKLEY e ALLOWAY, Valor Econômico, o5 de out. de 2011, p. C1). 
da acumulação efetiva de capital, pois interferem de forma crucial na estrutura de crédito e, principalmente, atuam como importante fator da mobilização de capital de empréstimo, que, como visto mais acima, é a seiva necessária da circulação creditícia capitalista.

\section{Sistema de Crédito e Sistema de Divida Pública}

Uma das funções específicas do sistema de crédito é disponibilizar fundos de empréstimo ao Estado capitalista, o que estabelece dois condicionantes centrais que deverão ser analisados: primeiramente as finanças públicas são componentes das finanças globais capitalistas, ou seja, deve-se entender o financiamento do Estado no interior das condições de expansão do capital; segundo, a capacidade de intervenção e regulação do Estado processa-se, principalmente, por dentro da dinâmica do sistema de crédito capitalista, por meio do sistema de dívida pública.

O sistema de dívida pública constitui-se tanto da divida estatal em si, ou seja, os empréstimos solicitados pelo Tesouro Nacional a Bancos, Organismos Financeiros e Fundos Institucionais públicos e privados ${ }^{17}$, quanto do mecanismo de conversão desta soma emprestada em títulos de dívida transferíveis e funcionalmente utilizáveis como se fosse capital monetário. Estruturalmente compõe parte do sistema de crédito global da economia capitalista, do qual constitui componente original.

A massa de títulos que constituem capital fictício faz parte do fundo de reserva dos bancos, especialmente os títulos de longo prazo da dívida pública, permitindo a concessão de novos créditos a partir da sua disponibilidade. Deste modo pode-se caracterizar o movimento de transação dos títulos da dívida pública como componente importante de regulação do sistema geral de crédito.

A funcionalidade de uma autoridade monetária é sempre bastante restrita. Como lembrou Marx (citado em Harvey, 1990, P. 310), "o poder do Banco Central começa onde termina o dos bancos privados", o que implica que o Banco Central tem poder de ação limitado, tanto pelas condições reais do ciclo de acumulação que determina as reservas monetárias originais quanto pela massa de valores fictícios que influenciam o sistema e aumentam a sua inerente instabilidade. Isso em função da expansão do crédito especulativo e do possível impacto que uma desvalorização generalizada desses títulos poderá provocar na acumulação real. O poder do Banco Central emana da

17 Os fundos de pensão e fundos de investimento são relativamente recentes, tratando-se de instituições que se desenvolvem inicialmente nas economias anglo-saxônicas, principalmente a partir dos anos 6o e 70, como observa Farnetti (1998). Sauviat (2005, p. 109) precisa que, ao "longo dos anos 80 e 9o, num contexto de aumento crescente das desigualdades de renda, os fundos de pensão e os mutual funds surgiram como os principais atores dos mercados financeiros...”. 
autoridade do Tesouro Nacional, seja pela gestão do fundo fiscal, seja pela capacidade de arbitrar a divida pública ${ }^{18}$.

Diferentemente das empresas capitalistas, que em última instância estão na dependência financeira do ciclo rotacional uniforme dos seus capitais, as finanças do Estado dependem das características reprodutivas de acumulação média do sistema, da sazonalidade de recolhimento dos tributos e fases dos ciclos de negócios.

Deste modo, pode-se adiantar que o crédito público, ao se basear tanto no volume disposto pelo Estado na forma de arrecadação fiscal (na média dos países em torno de 30\% do PIB) quanto na sua maior capacidade de endividamento interno e externo, torna-o dimensionalmente diferenciado e qualitativamente capaz de assumir a gestão monetária da economia, por meio do Tesouro Nacional e do Banco Central. Por outro lado, há, sem dúvida, uma inegável diferença entre a dívida privada e a dívida pública. Considerando a possibilidade de falência e destruição do capital que constitui uma empresa privada, isso estabelece a maior fragilidade ou grau de estabilidade dos títulos de dívida (ações e debêntures) de uma empresa. Mesmo multinacionais e aglomerados financeiros estão sujeitas a um processo de falência e desmonte em um prazo de tempo médio ${ }^{19}$.

Aspecto central é que, no caso de falência e de não recomposição falimentar e acionária da empresa, uma grande quantidade de títulos é simplesmente destruída. Tratando-se do Estado, sua perenidade estabelece uma lógica relativamente diferente: mesmo decretado o default, os títulos são somente parcialmente destruídos (desvalorizados). Em um determinado prazo, considerando crise local, esses mesmos títulos poderão novamente ser renegociados, muitas vezes ultrapassando o valor de face nominal pré-crise. $\mathrm{O}$ caso da Argentina (2001) é um bom exemplo ${ }^{20}$, o que tende a se repetir nos novos episódios da Grécia e, possivelmente, Portugal, Itália e Espanha.

Qual a influência dos títulos públicos sobre a oferta e demanda de capital de

18 Questionamento muito forte que surgiu desde o agravamento da crise financeira na Europa refere-se aos limites de funcionamento e existência de um Banco Central isolado, sem o compartilhamento de um Tesouro Nacional. Fiori (Valor Econômico, p. A15, 22 de set. de 2011) pondera que um dos pontos mais evidentes do descompasso econômico da Zona do Euro é "a falta de um tesouro europeu com capacidade unificada de tributar e emitir dívidas, junto com um BC capaz de atuar como emprestador de última instância”.

19 Os exemplos mais recentes são muitos: a Parmalat e a Enron no setor produtivo, no início da década de 2000 e, mais recentes, os grandes bancos estadunidenses como o Lehman Brothers e o Fannie Mae em 2008. Sauviat (2005, p. 128) observa que a falência da Enron é exemplar para demonstrar a fragilidade à qual estão expostos os chamados pequenos aplicadores e os assalariados vinculados a "fundos de pensão" com aplicações na bolsa de valores. Vale observar que os títulos soberanos de economias periféricas, a exemplo da Grécia atual e das economias latino-americanas (Brasil, Argentina e México) na década de 1990, em algum momento são resgatados, muitas vezes com expressivos ganhos de transferências.

20 Como obviamente é inevitável os "tubarões engolirem os peixes miúdos", com a moratória Argentina ficou visível, mais do que em outros episódios semelhantes, as manobras dos grandes bancos e financistas. Houve pequenos aplicadores em títulos argentinos que venderam os mesmos a um deságio de $70 \%$ sobre o preço de face. "O Merril Lynch comprou US\$ 6 bilhões e o bilionário mexicano Carlos Slim teria investido US $\$ 2$ bilhões”, por sua vez o "JP Morgan comprou bilhões em títulos em moratória de investidores particulares a menos de 29 centavos" e os venderia com um ganho real de quase 30\% (Conferir Carta Capital, n. 332, matéria de Antônio Luiz Costa e; KATZ, 2005). 
empréstimo ao longo do ciclo de negócios e como ele influencia a dinâmica do sistema de crédito capitalista? Dois aspectos, que são pontos centrais para desvencilhar a questão posta, devem ser analisados em sua conexão íntima com o sistema de dívida pública e emprego dos títulos da dívida estatal: o primeiro aspecto diz respeito a função de condicionamento da oscilação da taxa de juro média do sistema de crédito, a qual não é tratada neste artigo; o segundo aspecto trata-se de uma função reguladora muito específica, realizada pelos títulos estatais de longo prazo: a função absorção de capital de empréstimo, a qual nos deteremos mais apropriadamente a partir daqui.

De um modo geral, a elevação da dívida pública, representada na contrapartida da elevação exponencial de títulos de crédito em mãos dos credores do Estado, parece corresponder ao principal mecanismo moderno de preservação das propriedades monetárias do dinheiro de crédito, sendo uma engenharia monetária bastante frágil e fortemente dependente da continuidade de fluxos de crédito monetário (capital real) proveniente dos circuitos de acumulação globais e das condições internas de absorção desse fluxo de capital por parte da economia hegemônica, ou seja, os EUA, como se buscará demonstrar e analisar a seguir ${ }^{21}$.

\section{Divida Pública e a "Função Absorção de Capital de Em- préstimo"}

Os títulos da dívida pública constituem, ao lado dos títulos privados de empresas de capital aberto, a principal forma de capital fictício e geram um retorno na forma de renda que nada mais é do que uma parcela alíquota da receita tributária futura do Estado. Apesar de o credor da dívida pública poder reivindicar do Estado somente aquele coeficiente sobre os tributos, essa renda, na medida em que pode ser capitalizada em função das taxas de juros e do tempo de maturação dos títulos, torna-os passíveis de negociação, tornando-se uma propriedade cujo valor pode a qualquer momento ser convertido em dinheiro ou magnitude de capital de empréstimo no mercado de títulos secundários.

No século XIX os títulos públicos já se constituíam a forma mais crível de capital fictício, sendo que o desenvolvimento e a expansão dos mercados de títulos, na época, desenvolveram outras formas de papéis transacionáveis. No século XX e no atual, os títulos da divida estatal passaram a assumir funções específicas. As mais destacáveis foram a de fator mobilizador de capital de empréstimo (condicionante da taxa média de juro) e a de absorção de capital de empréstimo, mecanismo que age duplamente, ao mesmo tempo cancelando e repondo títulos na cadeia de empréstimos.

\footnotetext{
21 Não se deve descurar que no subsistema imperialista hegemonizado pela Alemanha, que hoje conforma a Zona do Euro, são os títulos alemães que convergem o papel de absorção de capital de empréstimo, marca do poder dirigente da economia alemã sobre as demais. Vale observar que nas economias asiáticas nenhuma delas se impôs, ainda, enquanto ponto focal de absorção de capital de empréstimo, antes sendo os maiores (China e Japão) fornecedores de capital de empréstimo destinados ao sistema imperialista estadunidense.
} 
Uma das principais funções da dívida pública sob o capitalismo desenvolvido é subtrair (absorver) valor na forma de capital monetário do processo de circulação creditícia, diminuindo o volume potencial de capital de empréstimo capaz de penetrar na circulação do tipo II, diminuindo a "seiva" nos canais da circulação vinculados propriamente ao processo reprodutivo e, portanto, valorativo do capital, o que possibilita regulação da taxa média de lucro.

Marx (1981b, p. 569) colabora para esta análise ao afirmar que a "pletora de capital de empréstimo se relaciona com a acumulação produtiva somente no sentido de lhe ser inversamente proporcional”. A acumulação de capital de empréstimo consiste no amontoamento de dinheiro que se pode emprestar desenvolvendo-se a pletora de capital de empréstimo na medida em que o sistema de crédito impulsiona a superprodução ${ }^{22}$ conforme as condições reprodutivas do capital. O sistema de dívida pública elide parte importante desse excesso, destruindo uma massa de valor que, de outro modo, iria desencadear a desvalorização de crescentes parcelas de capital, porém em um ritmo descontrolado.

O processo de crise de superprodução poderá levar à desestabilização do dinheiro de crédito - Marx refere-se à possibilidade da perda de suas "propriedades monetárias" -, o que abalaria o sistema como um todo ${ }^{23}$. Neste sentido, a função anticíclica do Estado capitalista se dá menos mediante o impulso dos gastos estatais e mais por meio da função reguladora de absorção de capital de empréstimo proporcionada pela emissão de dívida pública.

Trata-se, de fato, de retirada de valor (capital monetário) dos canais da circulação II e sua conversão em dinheiro a ser gasto (destruído) pelo Estado na circulação I, exercendo uma legitima "absorção" de excedente de capital-monetário, atuando sobre os fluxos de oferta até o limite dado pela manutenção da rentabilidade positiva dos capitais em aplicação produtivas, ou seja, como força contrária ao declínio da taxa média de lucro.

Esse entendimento parece expressar a compreensão de Marx (1981b, p. 479) que faz uma longa citação do "The Currency Theory Reviewed", com o aparente intuito de demonstrar a influência da dívida pública inglesa sobre a acumulação de capital-dinheiro, a qual é reproduzida abaixo a fim de ilustrar o entendimento desta função absorção de capital de empréstimo pelo sistema de divida pública das economias centrais:

22 As crises de superprodução podem ser uma consequência dos desequilíbrios entre os departamentos produtivos da economia (DI e DII), ou resultante da pletora de crédito no sistema (GROSSMAN, 1979).

23 Marx (1981b, p. 593) observa que, a fim de manter a estabilidade do sistema de crédito, "sacrifica-se o valor das mercadorias, para assegurar que exista no dinheiro esse valor mítico e autônomo". 
"Na Inglaterra há continua acumulação de riqueza adicional, (...) estamos expostos a acumulações periódicas de dinheiro procurando aplicação (...). Durante muitos anos, a divida pública absorvia grandemente a riqueza que sobrava na Inglaterra. Depois de ter atingido o máximo em 1816, deixou de absorvê-la, e assim todo ano havia uma soma de 27 milhões, pelo menos, que procurava outra oportunidade de investimento (...). Empreendimentos que precisam de muito capital para se efetivar e de tempos em tempos captam o excedente do capital desocupado ...são absolutamente necessários (...), para aproveitar as riquezas excedentes da sociedade juntadas periodicamente e que não podem colocar-se nos ramos habituais de investimento" (Marx, 1981b, p. 479).

Dadas as condições reprodutivas do capital, observa-se uma permanente superprodução de capitais que se exterioriza em um processo de crise e leva tanto à desvalorização do capital-mercadoria criado quanto à perda de valor da massa de capital constante fixado no circuito de acumulação.

Em função desse corolário os capitalistas detentores de capital de empréstimo adotam, em conjunturas (fases) específicas do ciclo de negócios, medidas que, sob o ponto de vista subjetivo, buscam resguardar de algum modo sua capacidade futura de expansão de valor (posse sobre títulos de direito da acumulação futura) e, sob o ponto de vista objetivo do processo de expansão/ contração da acumulação, dissipam uma parcela da massa de capital, que na forma de overacumulation suscita o declínio da taxa de lucro e a queda na taxa de acumulação, consequentemente a crise sistêmica. Deste modo, a demanda por títulos estatais configura uma função anticíclica, postergando a crise de superacumulação de capital, absorvendo uma parcela da "seiva" que inunda o sistema e destruindo uma parcela dessa "riqueza excedente".

A função absorção de capital de empréstimo da dívida pública significa retirar dinheiro da circulação capitalista ou que teve sua circulação parcialmente interrompida, ou seja, implica destruir capital de empréstimo, convertendo-o em renda a ser gasta ou despendida pelo Estado. No capitalismo, a única forma de o dinheiro se conservar é como capital-dinheiro, jogando-se permanente e indefinidamente na circulação capitalista, pois o que se adianta no processo de acumulação não é dinheiro e sim capital-dinheiro. O dinheiro, como forma autônoma do valor, não é adiantado e sim despendido, gasto de forma não capitalista como renda, consumido em troca de valores de uso que são completa ou parcialmente destruídos, seja por capitalistas seja por seus agentes do Estado.

O desembolso de dinheiro para aquisição de títulos públicos representa a conversão de capital monetário em forma renda do dinheiro, havendo transferência ao Estado de uma magnitude valor que será transformado em valores de uso por esse agente. Em troca, os portadores dos títulos públicos disporão 
de dinheiro na função de unidade de conta ${ }^{24}$ que será capital-latente, enquanto permanecer nessa forma específica.

Na medida em que toda circulação mercantil é circulação capitalista, a única forma de reter valor monetário fora da circulação do capital seria mediante uma forma dinheiro-mercadoria qualquer, ouro, por exemplo, o que nas atuais condições do capitalismo desenvolvido não parece ser uma possibilidade convencional. Deste modo, a conversão de reserva de valor monetário (capital de empréstimo) em títulos de propriedade sobre renda futura é uma consequência lógica para a reprodução do sistema, isso porque, ao mesmo tempo em que o capital de empréstimo será dissipado socialmente, utilizado como forma-dinheiro da renda pelo Estado, consumindo seu valor na forma de fundo público ou bens bélicos, o capitalista proprietário daquela magnitude monetária, trocada contra papel do Estado, tem a disponibilidade sobre o uso futuro de riqueza ainda a ser gerada, correspondente à contrapartida de direitos sobre o juro da dívida pública.

Esse mecanismo de esterilização de valor possibilita, em períodos normais, que o portador desses títulos, ao vendê-los, retome a capacidade de direção sobre uma massa de capital monetário que poderá ser investido no ciclo de acumulação capitalista ou revertido em nova aplicação rentista. O juro pago pelo Estado aos portadores dos títulos públicos não tem relação alguma com o capital despendido, ou seja, o juro pago, assim como a amortização do principal da dívida, é resultante da receita fiscal ou de novos capitais de empréstimo tomados pelo Estado na forma de novo endividamento ${ }^{25}$.

Entretanto, essa interpretação da crise financeira enquanto "momento" de adequação da estrutura creditícia à acumulação de capital constitui somente etapa parcial do movimento global. As crises financeiras constituem processos incontroláveis e com elevados custos sistêmicos. A crise de 29 e, ao que parece a atual crise financeira, são exemplos categóricos da dificuldade de se controlar o movimento de readequação da lei do valor.

O sistema busca soluções mais ou menos funcionais à continuidade da lógica de acumulação, mesmo que cada novo ingrediente que se acrescente a este caldo encontre o limite em processos de crise mais complexos. A dívida pública é uma forma funcional e parcialmente controlável de desvalorização de capital. Ela possibilita aos capitais sobreacumulados uma inversão lucrativa que não emana do seu próprio uso, pois é capital fictício, e sim da transferência de valores provenientes de aplicações produtivas.

24 Germer (1997, p. 17-23) esclarece a função unidade de conta do dinheiro observando que o capital, na medida em que é uma massa de valor, necessariamente é expresso em dinheiro, o que constitui a função unidade de conta, porém não se deve em nenhum momento confundir capital - que é valor em movimento - com dinheiro - que é uma forma estática do valor.

25 Marx (1985b, p. 927) lembra esta condição nos seguintes termos: “(...) o investimento de 1000 libras esterlinas em títulos do Tesouro a $3 \%$ nada tem que ver com o capital que proporciona o rendimento para pagar os juros da dívida pública" (sem grifos no original). 
Neste sentido, a destruição de capital de empréstimo em um determinado momento adia as condições de sobreacumulação, preservando, mesmo que somente parcialmente, as relações de propriedade capitalista que, de outro modo, em um processo de crise, seriam destruídas juntamente com a massa de capital desvalorizada ou destruída. Grossmann (1979, p. 363) observa que a "razão última para a exportação de capital não é o lucro mais elevado no exterior e sim a falta de oportunidade de investimento no próprio país". Do mesmo modo, a inversão em títulos públicos é uma decorrência do excesso de capital ocioso, que encontra nos títulos do Estado um porto que garanta, momentaneamente, segurança contra a desvalorização inevitável.

Historicamente a constituição do sistema de dívida pública inglês possibilitou aos britânicos não somente os "fundos de guerra", mas constituiu, ainda no século XVIII, a primeira e primitiva manifestação da função absorção de capital de empréstimo, pois a partir do declínio das "Províncias Unidas" (Holanda), "o capital holandês começou a optar, cada vez mais maciçamente, pelos investimentos ingleses" (principalmente títulos da dívida pública), "com isso mantendo as finanças britânicas com relativa saúde” (Braudel, citado por Arrighi Et Al, 2001). A dívida pública inglesa absorveu o primeiro grande fluxo de capital de empréstimo moderno, constituído pelo capital holandês. Do mesmo modo, em meados do século XIX se observa o fluxo de capital de empréstimo inglês atravessar o Atlântico na forma de títulos da dívida pública estadunidense. Conforme Marx (1981a, p. 874), muito "capital que aparece hoje nos Estados Unidos, sem certidão de nascimento, era ontem, na Inglaterra, sangue infantil capitalizado".

\section{Os Limites da Absorção de Capital de Empréstimo e a Atual Crise Financeira}

Na atualidade, a dívida pública estadunidense absorve a maioria dos "fundos líquidos" internacionais. No final de 1997, os títulos do Tesouro americano em poder de "investidores" estrangeiros totalizavam US $\$ 1,23$ trilhão ou quase $36 \%$ do estoque em poder do setor privado (US\$ 3,4 trilhões), sendo os maiores detentores o Japão, a China, o Reino Unido e a Alemanha (Cintra, 2000). Segundo a Securities Industry and Financial Markets Association (SIFMA) em 2010 o volume diário de títulos do Tesouro estadunidense negociados chegou a US $\$ 500$ bilhões, sendo que $75 \%$ do estoque de títulos agora estão em poder de investidores estrangeiros (US \$ 3,3 trilhões), a China detendo US $\$$ 1,1 trilhão e o Japão US\$ 800 bilhões são os maiores detentores de títulos ${ }^{26}$.

Segundo dados do "The Levy Economics Institute", cerca de $75 \%$ do fluxo internacional de capitais é absorvido pelos EUA para financiar déficits orçamentários e em conta corrente. Em 2003, o passivo externo estadunidense 
chegava a US\$ 4,5 trilhões, sendo o déficit em conta corrente de US\$ 541,8 bilhões, cerca de 5\% do PIB dos EUA. Os bancos centrais da China e Japão têm acumulado uma grande quantidade de títulos estadunidenses, como parte de suas estratégias de manutenção de um "dólar forte" diante de suas respectivas moedas, o que é interessante para suas exportações. Essa forma de financiamento do déficit governamental estadunidense teve efeito de conter "tensões inflacionárias" e, vis-à-vis, manteve as condições de crédito ao consumidor americano em termos extremamente favoráveis durante toda a década de 1990 e metade da década de 2000 (conferir, Stiglitz, 2003, 2010; Belluzzo, 2005, 2010; Harvey, 2008, 2011).

\section{FIGURA 1: MÉDIA DE 10 ANOS DA DÍVIDA PÚBLICA MOBILIÁRIA FEDERAL - EUA (EM \% PIB)}

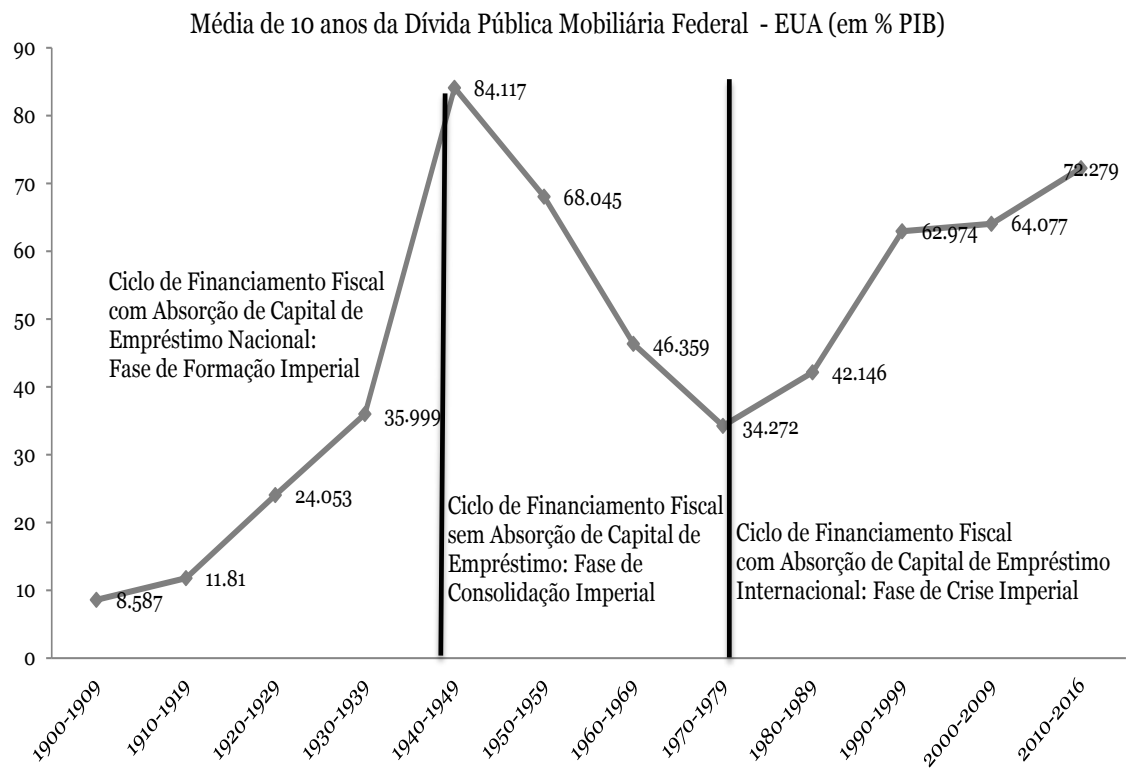

Fonte: http://www.usgovernmentspending.com. Acesso: 02/02/2012.

A análise desses processos inter-relacionados tem que considerar as condições específicas da acumulação de capital mundial, tomando-se tanto os circuitos nacionais (internos) de acumulação quanto os variados circuitos integrados na economia internacional. É válido, como observava Marx (1981b, p. 434-35) para a economia inglesa do século XIX, que os capitalista-monetários isoladamente vislumbrem o juro como um componente "autônomo" do processo reprodutivo geral da economia, porém é "naturalmente insensato generalizar essa possibilidade e estendê-la ao capital todo da sociedade, como o fazem alguns economistas vulgares". 
Os circuitos reprodutivos de acumulação integrados alimentam os dois circuitos de circulação monetária ${ }^{27}$, requerendo os títulos de renda permanentemente novos inputs de mais-valia, de tal maneira que a economia global se desenvolve distribuída em diversos circuitos nacionais de reprodução e centros de absorção de capital de empréstimo, cujo epicentro é o Estado Norte-Americano, pelo lado da absorção de capital de empréstimo, e as economias asiáticas, especialmente a China, pelo lado reprodutivo da mais-valia.

Pode-se pensar, em termos mundiais, que os circuitos de acumulação regionais ou nacionais funcionem como "capitalistas isolados" que alimentam um determinado fluxo permanente de capital de empréstimo, parcialmente absorvido por um contra fluxo de dívida pública da nação hegemônica, ou seja, a dívida pública funciona absorvendo capital de empréstimo e possibilitando o prolongamento das fases de ascensão dos ciclos de acumulação localizados. Contudo, no limite, a continuidade de alimentação integrada desses circuitos levará à crise de superprodução de capitais em termos globais. Ilustrativamente podemos conceber os fluxos econômicos entre os EUA e a China/Japão (bloco asiático) como estruturados dos seguintes momentos simplificados:

i) Os DI e DII reprodutivos daqueles países vendem aos EUA, constituindo o déficit comercial dessa potência. A produção bélica estadunidense requer uma troca permanente com os departamentos reprodutivos daquelas nações e, obviamente, também internos, o que leva às novas necessidades de trocas, principalmente em função da sobrecarga deste DII não reprodutivo (bens bélicos e bens de luxo) sobre os departamentos reprodutivos internos.

ii) Esse déficit comercial possibilita o acúmulo de capital-dinheiro (superávits reais) em mãos de capitalistas monetários (e Estados) asiáticos (e também europeus em parte).

iii) A dívida pública estadunidense absorve esse capital de empréstimo e alimenta o circuito internacional de crédito com uma crescente massa de títulos públicos. No curto prazo o circuito se fecha enquanto se mantiver a dinâmica de acumulação asiática, porém com uma crescente instabilidade monetária internacional ${ }^{28}$.

De Brunhoff (2005, p. 81-82) tem interpretação semelhante. Segundo ela, como "a maioria dos novos países capitalistas asiáticos, ela [a China] aplica

27 A Circulação do tipo I compreende a circulação monetária como dispêndio de renda, forma dinheiro da renda, que segundo Marx (1981b, p. 512) é meio de circulação "para o comércio (...) entre os consumidores individuais e os retalhistas, categoria em que se incluem todos os comerciantes que vendem aos consumidores - aos consumidores individuais que se distinguem dos consumidores produtivos ou produtores". A Circulação do tipo II, por outro lado, compreende a circulação de capital na forma dinheiro, sendo transferência de capital, seja como meio de compra (meio de circulação), seja como meio de pagamento.

28 A crise do próprio modelo neoliberal que, como teorizaram, entre outros Duménil \& Lévi (2005) e Harvey $(2008,2011)$ representou a reafirmação do poder da finança, exacerba o endividamento público estadunidense, se tornando particularmente agudo no período do segundo governo Bush. Episódio que demonstra a fragilidade sistêmica e que marcou a história recente refere-se ao impasse que foi gerado pela bancada republicana ao não aprovar os créditos orçamentários referentes a divida pública e que, entre outras consequências, levou ao rebaixamento de raiting dos títulos estadunidenses em 2011. 
seus excedentes em dólares em bônus do Tesouro norte-americano, o que contribui para fechar o circuito do crédito internacional norte-americano". Porém a "dívida estadunidense e a precipitação dos Estados Unidos na aventura iraquiana aumentaram cada uma a sua maneira, a instabilidade monetária internacional”. Há, portanto, plena integração entre os circuitos de acumulação asiáticos e a dívida pública estadunidense, porém o sistema tende a crescente instabilidade conforme aumenta a dependência da punção de mais-valia de um único grande ponto reprodutivo (China), e se enfraquece a capacidade fiscal da economia central (EUA).

Diversos autores têm defendido em relação ao caso estadunidense uma especificidade sui generis, qual seja a possibilidade de um crescimento indefinido da dívida pública daquele país, em função de que sua divida é nomeada em dólar, e na medida em que o FED pode controlar a taxa de juros e, em última instância, imprimir dólares, não haveria limites para os seus recorrentes déficits em transações correntes. Serrano (2004:217), por exemplo, afirma que, "ao contrário dos outros países onde a maior parte (quando não o total) dos passivos externos é denominada em outras moedas, os EUA detêm a prerrogativa de reduzir o serviço financeiro de sua dívida externa meramente através de uma redução das taxas de juros domésticas”.

Do mesmo modo raciocina Wray (2003:108). Segundo esse autor, o governo estadunidense pode vender títulos para estrangeiros desde "que estes títulos sejam denominados em moeda fiduciária interna”. Neste caso, “eles não implicarão quaisquer 'riscos' além daqueles que os títulos mantidos internamente". Parece-nos que essas análises são parcialmente equivocadas, podendo ser feitas as seguintes observações à luz do que foi até aqui exposto:

i) O limite para o endividamento do Estado é dado, principalmente, pela capacidade de expansão da carga fiscal, que naturalmente depende do crescimento interno da economia como consequência de maiores taxas de acumulação nos departamentos reprodutores internos da mesma ${ }^{29}$. Claro está que uma crescente sobrecarga financeira sobre esses departamentos, acompanhada de uma relação crescente de absorção de renda líquida por parte da dívida pública e sua posterior dissipação em gastos improdutivos, poderá, em um determinado período de tempo, minar as condições reprodutivas nacionais.

ii) Na medida em que o capitalismo é um sistema global cuja capacidade de expansão se regula pela existência de sistemas nacionais integrados e parcial-

29 Os gastos normais do Estado são a princípio financiados mediante uma tributação correspondente a um coeficiente fiscal sobre o valor líquido da renda nacional, ou seja, um percentual da mais-valia produzida anualmente ( T=iT.m). Deste modo, a renda liquida se destina aos gastos privados dos capitalistas e a gastos estatais. Este entendimento é demonstrado por Germer (2009) e parece ser a concepção central de Marx (1981c) quanto ao mecanismo de financiamento fiscal, tanto considerando o Estado como um agente participante da distribuição da riqueza e não tendo fonte própria de receita quanto pela condição de que parcelas significativas dos gastos estatais possam ser classificadas como socialmente necessárias à reprodução capitalista. 
mente dependentes entre i $^{30}$, pode-se estabelecer uma restrição dada pelo poder político e militar da nação devedora em relação aos credores externos. Contudo esse poder político e militar será tal como no aspecto anterior, minado, na medida em que as condições reprodutivas (econômicas) que sustentam essa ordem entrem em crise.

A superprodução de capital é o aspecto acionador das crises capitalistas, gerando o declínio da taxa média de lucro e a crescente necessidade de crédito monetário para fazer frente às dividas vincendas e aos empréstimos em descoberto por parte dos capitalistas. A superprodução necessariamente acarreta a desvalorização de capital-mercadoria e a perda da capacidade de meio de pagamento do dinheiro de crédito em circulação. Diante das dívidas vincendas e do questionamento da validade de parcela das notas de crédito, exige-se um crescente uso das reservas do Banco Central e, no limite, a maior intervenção deste organismo.

Três aspectos da dinâmica da dívida pública em momentos de crise podem ser assinalados: i) atua absorvendo capital de empréstimo excessivo, neste caso específico tem atuação anticíclica; ii) uma possível crescente necessidade por parte do Estado de recursos força a uma oferta crescente de títulos públicos no mercado primário, o que configura um fator a mais pela demanda de capitais de empréstimo. Neste segmento do ciclo de negócios a dívida pública é um componente a mais na pressão sobre a taxa de juro; iii) concomitantemente, a crescente necessidade de capital monetário por parte dos capitalistas em geral os leva a desfazer-se de uma massa crescente de títulos de capital fictício no mercado secundário.

A grande oferta de títulos, considerando o mercado primário e o secundário, produz um declínio no seu preço de face e conduz principalmente a uma redistribuição e concentração de valores nas mãos de um segmento de capitalistas em detrimento do segmento anterior.

Em tempos de crise no mercado monetário, os títulos públicos experimentam uma dupla depreciação: primeiro, porque o juro sobe e, segundo, porque se lançam em massa no mercado, para serem convertidos em dinheiro (notas do banco central). Num momento de crise, configura-se uma relação crítica entre a atuação da política fiscal e a da política monetária e, mais do que nunca, o Estado tem que agir como órgão de classe, convergindo sua atuação conforme os interesses dos setores da burguesia de maior poder financeiro. Pode-se observar que, em geral, em termos do financiamento do déficit fiscal, há um claro agravamento em função da impossibilidade de aumento da carga fiscal, dadas as condições de financiamento das empresas, a inadimplência e a massa crescente de títulos de crédito protestados.

30 A lógica do capital enquanto forma e conteúdo de desenvolvimento nunca se ateve aos limites nacionais, como já assim entendiam Marx\&Engels em seu famoso Manifesto do Partido Comunista. A referência de Brenner (2003, p. 14) de que a "evolução da economia americana" neste último quartel de século somente "parece compreensível no contexto do desenvolvimento da economia mundial" repõe corretamente o significado da obrigatória interação entre o nacional e o global na essência do capitalismo. 
Por outro lado, a situação do mercado financeiro pressiona a taxa de juro a elevar-se, atuando a política monetária no mercado aberto pela descompressão do mercado monetário, adquirindo títulos e ofertando notas do banco central a fim de reduzir a taxa de juro e aliviar os custos de financiamento das empresas. Contudo isso é no limite impossibilitado pela ausência de reservas monetárias que são sempre, ou principalmente, reservas fiscais. A solução é via mercado externo, ou pela entrada de capital de empréstimo externo, por meio da venda de títulos da dívida pública no mercado internacional, aumentando a dívida externa, mas aliviando no curto prazo a crise monetária, ou pela entrada de dinheiro via balança comercial ${ }^{31}$.

Esse conjunto de movimentos é bastante explicito na atual crise europeia, isso em parte em função de aspecto antes ponderado: a ausência de um Tesouro centralizado, com os poderes de taxação e emissão decorrentes. Vale observar que os interesses dos Estados europeus periféricos estão subordinados a preservação dos capitais de empréstimo dos bancos alemães e franceses. Neste sentido, o adiamento do default Grego, por exemplo, está condicionada a reciclagem dos títulos públicos gregos que compunham o portfólio daquelas instituições, por títulos garantidos dos Estados centrais, especialmente Alemanha e França, ou socialização das perdas mediante compra desses mesmos títulos, com o menor deságio possível, pelo Banco Central Europeu ${ }^{32}$.

A depender da gravidade da crise, a oferta de títulos públicos no mercado secundário se soma à oferta de títulos no mercado primário, pressionando o preço dos mesmos para baixo e, paralelamente à sua depreciação, a crescente centralização dos mesmos em mãos de credores externos. Marx (1981b, p. 538) observa que, após a crise, "os títulos [públicos] retornam ao nível anterior", contudo a sua depreciação atuou "poderosamente no sentido de centralizar a riqueza financeira".

A dívida pública absorve capital de empréstimo como condição funcional do sistema, diminuindo o maior fluxo (overacumulation) de capital, o que evita o declínio da taxa de juros de curto prazo e o possível aumento da especulação com títulos de crédito diversos. A forma como isso é feito, através de emissão de títulos de curto e longo prazo, acaba conferindo nova flexibilidade ao sistema de crédito, aumentando a massa de capital fictício na economia, o que fundamenta novos problemas, além de alimentar a desproporção entre departamentos (não reprodutivo, parte do DII e reprodutivos, DI e parte do DII) para financiamento dos gastos estatais.

31 Tem-se que analisar a possibilidade de soluções inflacionárias, via emissão de papel-moeda.

32 Feldstein (Valor Econômico, p. A13, o3 de out. de 2011) tem entendimento semelhante: "os bancos e outras instituições financeiras na Alemanha e na França têm grandes exposições a divida do governo grego (...). Adiar um default dará às instituições financeiras francesas e alemãs tempo suficiente para fortalecer sua base de capital". Em outros termos, os interesses de classe convergem o poder estatal a haute finance. 


\section{Considerações Finais}

Buscou-se neste artigo evidenciar, desde um aporte teórico marxista, as possíveis relações funcionais entre dívida pública e a capacidade financeira do sistema de crédito capitalista globalizado. Aspecto importante levantado refere-se aos limites que mesmo os Estados capitalistas centrais possuem de emissão de divida pública, por mais que uma das funções principais seja a absorção de capital de empréstimo.

Defendeu-se a tese que a divida pública cumpre uma função especifica de absorção de capital de empréstimo, que atua em termos convencionais como movimento de regulação da massa de capital de empréstimo do sistema capitalista global, inclusive possibilitando reciclagem de capital fictício, ou seja, reestruturando a pirâmide de crédito e transferindo valores dentro do sistema.

Finalmente cabe destacar que a dívida pública é, juntamente com outros mecanismos, uma saída somente temporária para a crise, pondo-se a cada processo estrutural de crise novos limites que impõem um grau de tensão cada vez maior, refletido tanto na pressão fiscal, necessária para fazer frente à elevação da carga financeira da divida pública, quanto pelos limites impostos ao refinanciamento da divida bruta pelo sistema de crédito internacional.

Podemos assim relembrar em relação à dívida pública estadunidense que o seu limite como grande absorvedor de excedentes de capital de empréstimo internacional está dado pela pressão fiscal futura sobre sua base reprodutiva, ao mesmo tempo em que as condições de domínio imperial pressionam por novas demandas por capital de empréstimo. Por outro lado, somente é cabível supor o refinanciamento da sua dívida pública externa mantida as condições de crescimento de economias que até aqui foram suas principais financiadoras, em especial na última década as economias asiáticas (China e Japão) que cumpriram papel central neste processo, alimentando o circuito internacional de capital de empréstimo e neste limite sustentando o frágil equilíbrio do capitalismo internacional deste início de século.

\section{Referências Bibliográficas}

ALTVATER, E. (2010). O fim do capitalismo como o conhecemos. Rio de Janeiro: Civilização Brasileira.

ARRIGHI, G., HUI, Po-keung, RAY, K. \& REIFER, T. E. (2001). “Geopolítica e altas finanças.” In: ARRIGHI, G. \& SILVER, B. J. Caos e governabilidade no moderno sistema mundial. Rio de Janeiro: Contraponto; Editora UFRJ.

ALLOWAY, T. (2012). "Uso de títulos de risco para garantir captação atinge 
nível de 2008 nos EUA.” Valor Econômico. Finanças, 2012.

BELLUZZO, L. G. (2005). Prefácio de “A Finança Mundializada”. In: CHESNAIS, F. A Finança Mundializada. São Paulo: Boitempo.

(2009). Os antecedentes da tormenta: origens da crise global. São Paulo: Editora UNESP; Campinas, SP: FACAMP.

. (2010). "A crise financeira além da finança”. Revista

Tempo do Mundo. Brasília: Ipea, pp. 117-129.

BRENNER, R. (2003). O boom e a bolha. Rio de Janeiro: Record.

CHESNAIS, F. (2005). "O capital portador de juros: acumulação, internacionalização, efeitos econômicos e políticos”. In: CHESNAIS, F (org.). A Finança Mundializada. São Paulo: Boitempo.

CINTRA, M. A. M. (2000). "A dinâmica dos mercados financeiros globais e as contradições da política monetária americana face à globalização financeira” . Ensaios FEE, Porto Alegre, v. 21 (2), pp. 183-206.

De BRUNHOFF, S. (1985). Estado e capital: uma análise da política econômica. Rio de Janeiro: Forense Universitária.

. (1998). "Money, Interest, and Finance in Marx's Ca-

pital”. In: BELLOFIORE, R.. Marxian Economics: a reappraisal essays on Volume III of Capital. New York: Macmillan Press ltd.

DUMÉNIL, G. \& LÉVY, D. (2005). “O neoliberalismo sob a hegemonia Norte-Americana”. In: CHESNAIS, F (org.). A Finança Mundializada. São Paulo: Boitempo.

DUPONT. D. \& Sack, B. (1999). “The treasury securities market: overview and recente developments". Federal Reserve Bulletin.

EICHENGREEN, B. (2000). A globalização do capital: uma história do sistema monetário internacional. São Paulo: Ed. 34.

FARNETTI, Richard. (1998). “O papel dos fundos de pensão e de investimentos coletivos anglo-saxônicos no desenvolvimento das finanças globalizadas.” In: CHESNAIS, F. A mundialização financeira: gênese, custos e riscos. São Paulo: Xamã.

FIORI, J. L. (2011). O custo intangível do fracasso europeu. Valor Econômico, Opinião, pp. A15, 22 de set. de 2011.

FELDSTEIN, M. (2011). Aposta europeia de alto risco. Valor Econômico, Opinião, pp. A13, 03 de out. de 2011.

FOLEY, D. (1990). "State expenditure from a Marxist perpective”. In: BAKER, S. H.; ELLIOTT, C. S. Readings in Public Sector Economics. Massachusetts: 
D. C. Heath and Company, 1990.

. (1990). “Asset speculation in Marx's Theory of Money”. In: BELLOFIORE, Riccardo. Marxian Economics: a reappraisal essays on Volume III of Capital. New York: Macmillan Press ltd, 1998.

GALBRAITH, J. K. (2004). A economia das fraudes inocentes: verdades para o nosso tempo. São Paulo: Companhia das Letras.

GERMER, C.M. (1995). Dinheiro, capital e dinheiro de crédito: o dinheiro segundo Marx. Inst. Economia/Unicamp: Campinas. Tese de Doutorado. Mimeografado.

. (1997). "Credit money and the functions of money in capitalism”. International Journal of Political Economy, v. 27 (1), pp. 43-72. . (2009). "Receita pública e circulação monetária na teoria de Marx”. Revista da Sociedade Brasileira de Economia Politica, v. 25, pp. 5-31.

GROSSMANN, H. (1979). La ley de la acumulación y del derrumbe del sistema capitalista. Madrid: siglo veintiuno.

HARVEY, D. (1990). Los limites del capitalismo y la teoría marxista. México: Fondo de Cultura Económica.

Paulo: Edições Loyola. . (2008). O neoliberalismo: história e implicações. São . (2011). O enigma do capital e as crises do capitalismo. São Paulo: Boitempo.

HILFERDING, Rudolf. (1985). O capital financeiro. São Paulo: Nova Cultural. HORNE, J. C. V. (1972). Funções e análise das taxas de mercado de capitais. São Paulo: Atlas.

ITOH, M.; LAPAVITSAS, C. (1997). Political Economy of Money and Finance. (mim.).

KATZ, C. (2005). “Quién gana com el canje?”. In: Publicación de los Economistas de Izquierda (EDI), ano 1, n. 1, pp. 11-23.

KINDLEBERGER, C. P. (2000). Manias, Pânico e Crashes: uma história das crises financeiras. Rio de Janeiro: Nova Fronteira.

MARX, K. (1977). Elementos Fundamentales para la Critica de la Económia Política (Borrador) 1857-1858, v. I e II. México: Siglo xxi Argentina Editores. . (1981a). O Capital: crítica da economia política. Livro 1, v. II. Rio de Janeiro: Civilização Brasileira. 
. (1981b). O Capital: crítica da economia política. L. 3, v. V. Rio de Janeiro: Civilização Brasileira. . (1985a). Teorias da Mais-valia. V. I. São Paulo: Difel, 1985a. . (1985b). Teorias da Mais-valia. V. II. São Paulo: Difel. . (1985c). Teorias da Mais-valia. V. III. São Paulo: Difel.

MINSKY, H. P. (2009). Estabilizando uma economia instável. Osasco, SP: Novo Século Editora.

OAKLEY, D.; ALLOWAY, T. (2011). Seguro contra calote na UE dispara. Valor Econômico, Finanças, p. C2, o5 de out. de 2011.

SANDRONI, P. (2001). Novíssimo Dicionário de Economia. São Paulo: Editora Best Seller.

SAUVIAT, C. (2005). "Os fundos de pensão e os fundos mútuos: principais atores da finança mundializada e do novo poder acionário”. In: CHESNAIS, F. A Finança Mundializada. São Paulo: Boitempo.

SERFATI, C. (2006). "A economia política da finança global”. Revista de Sociedade Brasileira de Economia Política, v 18.

SERRANO, F. (2004). "Relações de Poder e a Política Macroeconômica Americana, de Bretton Woods ao Padrão Dólar Flexível”. In: FIORI, J. L (org.). O Poder Americano. Petrópolis: Editora Vozes.

STIGLITZ, J. E. (2003). Os exuberantes anos 9o: uma nova interpretação da década mais próspera da história. São Paulo: Companhia das Letras.

. (2010). O mundo em queda libre: os Estados unidos, o mercado libre e o naufragio da economía mundial. São Paulo: Companhia das Letras.

TRINDADE, J. R. B. (2011). “A dívida pública como componente estrutural do sistema de crédito”. Revista Econômica, v 13 (1), pp. 94-125.

- (2012). "Sistema de crédito e oferta global de capital de empréstimo". Revista de Sociedade Brasileira de Economia Política, v 32, pp. 37-68.

WEEKS, J. (1981). Capital and Exploitation. Princeton: Princeton University Press,.

WRAY, L. R. (2003). Trabalho e moeda hoje: a chave para o pleno emprego e a estabilidade dos preços. Rio de Janeiro: Contraponto.

Recebido em: 2 de novembro de 2013

Aceito em: 19 de maio de 2014 